\begin{tabular}{l|l|l|l|l}
\hline Volume 1 & Issue 3 & October (2021) & DOI: & Page: $229-236$
\end{tabular}

\title{
Review on Effects of Sowing Methods and Types of Inorganic Fertilizers on Growth Yield and Yield Component of TEFF [Eragrostis TEF (ZUCC.)
}

\author{
Damte Balcha Gadana \\ Department of Plant Science, College of Agricultural Science, Wolaita Sodo University, Ethiopia \\ Corresponding Author: Damte Balcha Gadana; Email: balchadamte@gmail.com
}

\begin{abstract}
A R T I C L E I N F O
Keywords: Growth, Inorganic Fertilizer, Sowing Methods, Yield.

Received : 11 June 2021

Revised : 21 October 2021

Accepted : 25 October 2021

A B S T R A C T

Most farmers' practices broadcast sowing methods and productivity is less. Soil fertility maintenance is a major concern in tropical Africa which needs to tackle soil fertility depletion as a fundamental constraint. Similarly, the traditional way of planting tef reduces the amount of grain production, promotes competition for inputs, and causes severe lodging. This paper aimed to review the interaction effects between seed sowing methods and different types of inorganic fertilizers on the growth and yield of teff. In Ethiopia, recent research indicates planting method (row planting and broadcasting) affects the yield and yield components of teff. The review indicates the yield components include heading and maturity, plant height, first growth rate, number of tiller and panicle, thousand seed weight, grain, straw, and total biomass yields and harvest index high in Method of Row sowing compared to broadcast in Ethiopia but Days to emergence and panicle length were more affected by broadcasting. In economical acceptance, Row sowing was found to be economically acceptable with more income from grain yield than broadcasting.
\end{abstract}

\section{INTRODUCTION}

Tef [Eragrostistef (Zucc.) Trotter] is an annual C4 grass that belongs to the family Poaceae (Kebedeet al., 1989). It is an indigenous cereal crop in Ethiopia. Ethiopia is the origin and the first domesticator of this unique crop (Vavilov, 1951). It occupies about 2.7 million hectares $27 \%$ of the grain crop area) of land which is more than any other major cereals such as maize $22.7 \%$, sorghum $19 \%$, and wheat $16 \%(\mathrm{CSA}, 2010)$. Of the $82 \%$ gross grain production (about 17 million tonnes) contributed by cereals, tef constituted $19.9 \%$ during the main season of 2010/11 (CSA, 2010). Ethiopian farmers grow tef for several merits, which are mainly attributed to the socio-economic, cultural, and agronomic benefits (Seyfu, 1993). Tef has much or even more food value than the major grains such as wheat, barley, and maize. Tef grain contains $14-15 \%$ proteins, $11-33 \mathrm{mg}$ iron, $100-150 \mathrm{mg}$ calcium, and is rich in potassium and phosphorus nutrients (National Academy Press, 1996). Tef has got many prospects outside of Ethiopia due to its gluten-freeness, tolerance to biotic and abiotic stress, animal feed, and erosion control quality.

Tef production has been increasing from year to year and so does its demand as the staple grain in both rural and urban areas of Ethiopia (Mitiku, 2008). Although tef is found in almost all cereal growing areas of Ethiopia, the major areas of production are Shewa, Gojam, Gonder, Wello, and Wellega with central highlands of the country (Doris Piccinin, 2010). Tef is predominantly cultivated on sandy-loam to black clay soils. Moreover, tef withstands low moisture conditions and is often considered as a rescue crop that survives and grows well on residual soil moisture in the season when early planted crops (e.g. maize) fail due to low moisture. In addition, its ability to tolerate drainage problems makes it a preferred cereal by farmers and becomes a highly valued crop primarily grown for its grain that is used for making injera (Abel, 2005). It is typically hand-broadcasted on the field and, in most cases, seeds are left uncovered. Tef can produce a crop in a relatively 
short growing season and will produce both grains for human food and fodder for cattle (Seyfu, 1997). Tef is relatively free of plant diseases when compared to other cereal crops. In Ethiopia, in locations where humidity is high, rusts and head smuts are important diseases. About 22 fungi and 3 pathogenic nematodes have been identified on tef (Bekele, 1985). Teff seedlings are also susceptible to damping-off caused by Drechslerapoae and Helminthosporiumpoae (Baudys) Shoemaker when sown too early (Ketema, 1987).

Insect pests of tef in Ethiopia include Wellobush cricket, Decticoidesbrevipennis, red tef worm, Mentaxyaignicollis, tef Epilachna, and tef black beetle (Stallknechet al., 1993). The objectives of the paper are to review the interaction effects between seed sowing methods and different types of inorganic fertilizers on the growth and yield of teff

\section{RESULTS AND DISCUSSION Importance of Teff}

In Ethiopia, tef has been predominantly grown as a cereal crop and not as a forage crop. However, when grown as a cereal, farmers highly value its straw as an invaluable and very important source of animal feed, especially during the dry season (Seyfu, 1997). Tef straw is also used to reinforce mud and plaster the walls of tukuls and local grain storage facilities called gotera (Seyfu, 1997).

Tef serves as a cash crop because both its grains and straw fetch higher market prices than that of other cereals (Seyfu, 1997; Hailu et al., 2000). Because of its wide ecological adaptation, hardiness, higher prices of both the grain and straw, and highly preferred quality for injera making, farmers give it high priority both as food and cash crop (Seyfu, 1997).

Hailu and Seyfu (2001) suggested that there is an increasing tendency for tef export from year to year to the Middle East, North America, and Europe mainly for Ethiopian immigrants. Limited cultivation for both grain and forage has also begun in the USA (Asrat and Frew, 2001).

\section{Ecological Requirements of Teff}

Tef is adapted to a wide range of environments and is presently cultivated under diverse agroclimatic conditions (Minale et al., 2003). It can be grown from sea level up to $2800 \mathrm{~m}$ a.s.l, under various rainfall, temperature, and soil regimes (Seyfu, 1997). However, according to experience gained so far from national yield trials conducted at different locations across the country, tef performs well at an altitude of $1800-2100 \mathrm{~m}$ a.s.l, annual rainfall of 750-850 $\mathrm{mm}$, growing season rainfall of $450-550 \mathrm{~mm}$, and a temperature range of $10^{\circ} \mathrm{C}$ $27^{\circ} \mathrm{C}$ (Seyfu,1997). A very good result can also be obtained at an altitude range of 1700-2200 m and growing season rainfall of $300 \mathrm{~mm}$ (Seyfu, 1997).

\section{Response of Crops to Sowing Method}

Broadcasting as one of the seed sowing methods, and in combination with reduced cultivation offers the advantage of being up to four times faster than conventional plowing and drilling and is of particular value for sowing large hectares of winter cereals (Ball, 1996). Grass seed fields may be seeded by broadcasting or in rows depending on the available equipment, moisture content, and species. Henning and Risner (1993) suggested seeding of orchardgrass can be made by broadcasting as the seeds are very small. Broadcast method of planting is less expensive, uneven seeds distribution, high competition among plants at a certain area and no competition at all in other areas takes place in the field, no or less tillering, thin stalk, light, and short panicle length and less time taking (Hunt, 1999). It also decreased in water use efficiency and fertilizer efficiency and difficulty of controlling weeds by inter cultivation. To avoid uneven stands, improve tillering, improve yield attributing parameters, reduce lodging and decrease competition among plants, row planting is preferred although it is tedious, time taking, and needs a qualified person (Hunt, 1999). Row planting will help in controlling weeds, especially mechanical control by inter cultivation and management of the crop and maintaining the optimum density of seedlings. Row seeding of germinated seeds could also be done but it is practiced on a limited scale because of its costs and difficulty in obtaining implements (Chatterje and Maiti, 1985). Ballock et.al.,(2002) indicated that wider spacing had a linearly increasing effect on the performance of individual plants as they draw more nutrients from surrounding and more solar radiation for a better photosynthetic process which inter produces more effective tiller numbers and longer panicle length per each tiller than dense once. According to Mitiku (2008), there was a significant increase in yield components of tef with decreased seed rates from highest to lowest $(35,30,25,20$, kgha-1). On the 
other hand, the lodging percentage of the crop was increased by increasing the seed rates. Guitard et al, (1961) reported that an increase in seeding rate caused a linear increase in the number of plants per acre and a curvilinear decrease in the number of fertile heads in wheat, oat, and barley. They also reported that as there is an associated reduction in the number of kernels per head and thousand kernel weights, but the type of response varies with the crop

\section{Nutrient Requirement of Tef}

The growth, development, and yield of cereal crops can be adversely affected when there is a deficiency or excessive supply of any of the essential elements and other toxic substances (Hay and Walker, 1992). Soil productivity is also dependent on soil physical, chemical, and biological characteristics (Tekalignet al., 1996). Continuous cultivation of arable land without nutrient inputs results in degraded soils, accelerated soil erosion, depletion of soil nutrient reserves, reduced soil OM content, deterioration of soil physical structure, and reduced crop productivity. The continuous removal of biomass (grain and crop residues) from cropland nutrient replenishment can rapidly deplete the soil nutrient reserves and jeopardize the sustainability of agricultural production (Legesse, 2004). without adequate

\section{Nitrogen}

Nitrogen plays a central role in plant biochemistry being an essential constituent of the cell wall, a cytoplasmic protein, nucleic acids, chlorophyll, and other cell components (Hay et al., 1992). As a result, deficiency in the supply of $\mathrm{N}$ has a profound effect on crop growth and development and can lead to a total loss of grain yield in extreme cases (Miller and Donahue, 1995). The nitrogen exerts its influence on crop growth in various ways. It promotes rapid growth and increases tiller production.

High Nitrogen rates stimulate root and leaf growth and thereby increase photosynthetic activity and growth (Evans, 1993). Nitrogen plays a predominant role among the soil nutrients in crop production (Hay et al., 1992). The number of nutrients required to optimize or sustain crop production depends on the inherent capacity of the soil to supply adequate levels of nutrients to the growing plants, the yield potential of the crops, a variety grown, and the availability and cost of fertilizers (Tilahun, 1994). Among macronutrients, $\mathrm{N}$ is ranked first in limiting sustainable crop production (Tisdale et al., 1993).

In growing high yielder tef varieties, $\mathrm{N}$ deficiency limits production more often than any other factor (Legesse, 2004). N helped the production of more straw while $\mathrm{P}$ ensured good grain production whereas $\mathrm{K}$ was found to have a minor effect on tef production (Temesgen, 2001). Excess $\mathrm{N}$ supply causes higher photosynthetic activity and vigorous vegetative growth which is disadvantageous early in the growing season when moisture limits plant growth, and is accompanied by weak stem. Dark green color, low product quality, delay in maturity, increase in susceptibility to lodging, insect pests and diseases (especially fungal diseases), and build-up of nitrite which is harmful to foliage and straw feed are common effects of excess $\mathrm{N}$ application in tef (Temesgen, 2001; Legesse, 2004). Grain and straw yield response of tef to increasing rates of $\mathrm{N}$ was highly significant on Vertisols (AUA, 1989). However, the yield obtained due to the application of the highest rate of $\mathrm{N}(92 \mathrm{~kg} / \mathrm{ha})$ was not significantly different from the yield obtained by applying $69 \mathrm{~kg} / \mathrm{ha}$ (AUA, 1989). High rates of fertilizers can be applied to tef at the time of sowing with the seeds on the bare land without any harm to the germination rates of tef seeds (Alkamer, 1973). According to Temesgen (2001), the application of different levels of $\mathrm{N}$ fertilizer affected grain, straw, and biomass yield significantly on farmer's fields.

As applied $\mathrm{N}$ rates increased, the grain uptake also increased which was also reflected in the plant height, yield, and yield components like panicle length, panicle weight, grain yield, straw yield, and biomass yield (Legesse, 2004). The same author further stated that the straw $\mathrm{N}$ uptake was significantly increased as the applied $\mathrm{N}$ rate increased. Similarly, the application of $\mathrm{P}$ fertilizer significantly affected straw $\mathrm{N}$ uptake though the increment was inconsistent.

\section{Phosphorus}

Phosphorus is the second most essential element for crop production to achieve maximum yields (Legesse, 2004). A good supply of P has been associated with increased root growth and a stiff stalk to resist lodging (Miller and Donhue, 1995). Although $P$ is essential for photosynthesis and other Physico-chemical processes in the plant, it 
is deficient in most agricultural soils or where fixation limits its availability (FAO, 2000). In cereal crops good P nutrition strengthens structural tissues such as straw or stalks, thus helping to prevent lodging (Brady and Weil, 2000).

Thus, sustainable crop production is impossible without the application of $\mathrm{P}$ fertilizers (Sanchez et al., 1996). Contrary to this, the application of $\mathrm{P}$ had shown a non-significant effect on crop phenology, growth, lodging percentage, and yield and yield components of tef on Vertisols (Legesse, 2004).

Soils containing large quantities of clay will fix more P than soils with low clay content. In other words, the more surface area exposed with a given type of clay, the greater the tendency to adsorb (Tisdale et al., 1993). Soils that are prone to strong phosphate fixation and adsorption to sesquioxides and clay minerals often require extremely high phosphate fertilizer application to alleviate the effects of fixation. In these strongly phosphate fixing soils, $\mathrm{pH}$ correction is also recommended, since phosphate adsorption is especially high at low $\mathrm{pH}$ levels. As the mobility of the $\mathrm{P}$ in the soil profile is comparatively low, the uptake of fertilizer $\mathrm{P}$ depends much on the root growth and morphology of the crop being considered. In most mineral soils mobility of $\mathrm{P}$ is rather low so that fertilizer $\mathrm{P}$ is scarcely leached in to the deeper soil layers (Mengel and Kirkby, 1996). According to Legesse (2004), the total P uptake was significantly increased as the applied $\mathrm{P}$ rate increased but this increase was not reflected in an increase in growth, yield, and yield components at all. The same author reported that total $\mathrm{P}$ uptake was increased significantly due to the application of $\mathrm{N}$, and maximum $P$ uptake by tef was recorded due to 20 $\mathrm{kg} \mathrm{P} / \mathrm{ha}$ and $69 \mathrm{~kg} \mathrm{~N} / \mathrm{ha}$. Therefore, to get optimum yield, a high amount of $\mathrm{P}$ application is needed to satisfy the fixing ability of the soil and increase yield (Legesse, 2004). Phosphorus application did not significantly affect panicle and grain weight, panicle length, plant height, harvest index, Biomass, grain, and straw yield of tef (Legesse, 2004). Grain $P$ content also showed an inconsistent trend with the increase in the application rate of $\mathrm{P}$ while the straw $P$ remained almost the same (Legesse, 2004). This could be due to the high Ca-saturated clay content of the experimental soil under study, which might have made $\mathrm{P}$ fertilizer precipitate or adsorb as a result plants could not recover $P$ fertilizer.

\section{Potassium}

It is known that Ethiopian soils are highly prone to erosion and leaching of essential elements like $\mathrm{Mg}, \mathrm{S}$, and $\mathrm{Zn}$ due to the high rainfall and undulating topography of most arable lands. But no fertilizer containing these elements is commonly used by Ethiopian farmers to replace the losses due to leaching and crop removal. Their role, however, is not less than $\mathrm{N}$ and $\mathrm{P}$ which are mostly applied to increase crop growth and development (Amareet al., 2005). Potassium plays more roles in a plant than any other nutrient (Brady and Weil, 2000). It does not become a direct part of plant structure, but acts to regulate water balance, nutrient, and sugar movement in plant tissue, plus drives starch and protein synthesis and legume nitrogen fixation. It is involved in enzyme activation in many important plant physiological processes and over 80 plant enzymes require $\mathrm{K}$ for their activation (Brady and Weil, 2000). Many processes of plant physiology like maintenance of turgor during stress conditions, transpiration, production of high energy molecules, translocation of assimilates are mostly regulated by the presence of $\mathrm{K}+$ in the plant tissue. Thus, plant requirements for available $\mathrm{K}$ are quite high (Tisdale et al., 1993). Potassium is taken up by plants in its ionic $(\mathrm{K}+)$ form from soil solution by roots. The concentration of $\mathrm{k}+$ in vegetative tissue usually ranges from $1-4 \%$ on a dry matter basis. $K$, unlike $\mathrm{N}, \mathrm{S}, \mathrm{P}$, and other nutrients, it forms no coordinated compounds in the plant. Instead, it exists solely as $\mathrm{K}+$ ion, either in solution or bound to charges on organic radicals. As a result of its restricting ionic nature, $\mathrm{K}+$ has got profound functions particularly related to the ionic strength of solutions within plant cells.

The various functions of potassium lead to a wide array of symptoms when it is deficient such as slow growth, poorly developed root system, weak stems, and frequent lodging due to weak cell wall structure, lower yields, smaller and shriveled seed, more susceptibility to diseases, poor water use efficiency and poor $\mathrm{N}$ uptake. Its deficiency may also cause the weakening of straw in grain crops, which causes lodging in small grains and stalk breakage in maize (Tisdale et al., 1993). According to Mulubrhan (2005), the application of K did not produce substatuber weight, total tuber yield, 
marketable tuber yield, and tuber yield per hill, but the interaction of $\mathrm{K}$ with $\mathrm{N}$ and $\mathrm{P}$ resulted in a significant difference in total tuber yield, total tuber yield per hill, average tuber yield of potato. However, the information is missing for potential effect.

\section{Sulfur and Magnesium}

Sulfur is absorbed by plant roots exclusively in the form of sulfate (SO4-2) and is an essential element for plant growth and the physiological functioning of plants. Khurana and Chatterjee (2002) stated that sulfur is the fourth important major nutrient after nitrogen, potassium, and phosphorus, as it is essential for the formation of proteins, being a constituent of amino acids and fatty acids. The sulfur requirement varies strongly between species and it may fluctuate during plant growth (Haneklaus, 2007). A sulfur deficiency can change the concentration of proteins, resulting in increased dough strength in wheat, reducing spikelet initiation and /or floret, increased mortality of florets, and to a less extent reduced tillering and grain weight, and finally yield (Haneklaus, 2007). The sulfur deficiency is most likely to occur in areas of high rainfall as it is prone to leaching as $\mathrm{N}$ and no use of organic fertilizers as the main source of sulfur (organic matter) (Haneklaus, 2007). Sulfur deficiency is caused due to low or no inputs of fertilizers, low organic matter level of the soils, and higher-yielding varieties that deplete the reserves of soil S. Adequate supply of sulfur fertilizer improves the $\mathrm{N}$ use efficiency by reducing the $\mathrm{N} / \mathrm{S}$ ratio, increasing the protein content of grains and increase yield as a whole (Epstein, 1992). The chlorophyll development is much reduced when magnesium uptake is restricted because it is an integral part of the pigment. It maintains the dark-green color of leaves and regulates the uptake of other materials, particularly nitrogen and phosphorus and it appears to play an important role in the transport of phosphorus, particularly into the seeds and both its uptake and translocation is high at the low level of the soil $\mathrm{K}(40-50 \mathrm{mg} / \mathrm{kg}$ of soil) (Pilbeam and Kirkyby, 1983). It is also said to promote the formation of oils and fats, possibly by increasing photosynthetic activity in the leaves.

\section{Micronutrients}

As with any plant nutrient, many soil factors influence the availability of micronutrients to plants. Among the most important factors are soil solution $\mathrm{pH}$ and organic matter (Mortvedt, et al., 1991). The same author also states that micronutrients are equally important for plant growth and development as a macronutrient in spite of their quantity. Though they are required in small quantity, a plant cannot complete its life cycle, does not set true fruit, in the deficiency of micronutrients (Mortvedt, et al., 1991).

Zinc is absorbed by plants in the form of $\mathrm{Zn}+2$ and its deficiency is the most widespread micronutrient throughout the world (Mortvedt, et al., 1991). Zinc availability to plants is influenced by soil $\mathrm{pH}$, organic matter, interactions with other nutrients, and climatic conditions (Barber, 1994). Zinc is an essential component of various enzyme systems for energy production, protein synthesis, and growth regulation.

Zinc deficiencies are mainly found on sandy soils low in organic matter and on organic soils (Barber, 1994). Zinc deficiencies occur more often during cold, wet spring weather and are related to reduced root growth and activity as well as lower microbial activity decreases zinc release from soil organic matter. Zinc deficiency is expected to occur in areas of relatively high $\mathrm{pH}$ as its concentration in soil solution decreases threefolds per unit increase in $\mathrm{pH}$. At high $\mathrm{pH} \mathrm{Zn}$ precipitates as insoluble amorphous soil $\mathrm{Zn}, \mathrm{ZnFeO} 4$, and $\mathrm{ZnSiO} 4$ and liming acid soils will reduce uptake of zinc, which is related to the $\mathrm{pH}$ effect on $\mathrm{Zn}$ solubility (Barber, 1994). Zinc is very important in increasing the size of leaf, stem, or stalk internodes, and promotes apical dominance which is directly related to the yield potential of cereal crops (Epstein, 1992).

\section{Nutrient Interactions}

Interactions occur when the supply of one nutrient affects the absorption, distribution, or function of another nutrient. The result may induce deficiencies, toxicities, modified growth responses, and/or modified nutrient composition (Robson and Pitman, 1993). If two nutrients are limiting, or nearly limiting growth or composition (concentration) were adding only one of the nutrients has little effect while adding both gives a considerable effect, the effect is said to be a positive interaction. Similarly, if adding the two together has less effect than when each is added separately, the effect is said to be negative interaction and when the same, no interaction (Martin, 1993). Nitrogen can increase $\mathrm{P}$ concentrations in plants by 
increasing root growth, by increasing the ability of roots to absorb and translocation $\mathrm{P}$, decreasing soil $\mathrm{pH}$ as the result of absorption of $\mathrm{NH} 4+$ and thus increasing the solubility of fertilizer $\mathrm{P}$ (Miller, 1996). Responses to both $\mathrm{N}$ and $\mathrm{P}$ are small at low levels of the other nutrients, but increase markedly for the combination of $\mathrm{N}$ and $\mathrm{P}$ at higher rates of $\mathrm{N}$ and $\mathrm{P}$. Nitrogen stimulated the uptake of $\mathrm{P}$ and vice versa. The synthesis of chlorophyll, uptake of $\mathrm{N}$ assimilation, and activity of nitrate reductase are strongly dependent on the sulfur content of the soil (Epstein, 1992). Mg regulates the uptake of other materials, particularly nitrogen and phosphorus and it appears to play an important role in the transport of phosphorus, particularly into the seeds (Pilbeam, and Kirkyby, 1983). Generally the concentration of $\mathrm{Mg} 2+$ in soil solution is higher than that of $\mathrm{K}+$ but the uptake of $\mathrm{Mg} 2+$ by root hairs is much lower than the uptake rate of $\mathrm{k}+$ (Epstein, 1992). The reason for this behavior is, cat ion competition may play a major role and $\mathrm{Mg} 2+$ uptake can be seriously affected by access to other cation species, especially $\mathrm{K}+$ and $\mathrm{NH} 4+$. This competition leads to $\mathrm{Mg}$ deficiency in plants.

The level of $\mathrm{N}$ nutrition required for optimum growth during the vegetative e period must be balanced by the presence of other plant nutrients in adequate amounts (Cocucci and Dallarosa, 1980). Both uptake of nitrate and its assimilation into protein is also considerably influenced by the $\mathrm{K}$ status of the plant (Cocucci and Dallarosa, 1980). K is important for growth and elongation and has a synergistic effect with indole acetic acid and gibberellic acid.

\section{ConCLUSION}

It is an indigenous cereal crop in Ethiopia. Ethiopia is the origin and the first domesticator of this unique crop. The time of DAP application and sowing method varies from farmer to farmer. Therefore, there is a need to determine the time of DAP and sowing method recommendations for tef. Generally accordingly, Berhe (2009) recent Development in teff Ethiopian, The economic analysis indicated that row sowing had acceptable MRR (627.7\%); and 6775.6 Birr ha-1 more grain yield income than broadcasting tef. In Ethiopia, teff has been predominantly grown as a cereal crop and not as a forage crop. However, when grown as a cereal, farmers highly value its straw as an invaluable and very important source of animal feed, especially during the dry season. Continuous cultivation of arable land without nutrient inputs results in degraded soils, accelerated soil erosion, depletion of soil nutrient reserves, reduced soil OM content, and deterioration of soil physical structure, and reduced crop productivity. However, it is advisable to undertake further research across soil type, years, and locations to draw sound recommendations on a wider scale.

\section{REFERENCES}

1. Alkamer, J. (1973). The fertilization of TEF. Journal of Associated Advanced Science, Africa (1):56-65.

2. Amare Hailesilasie, J.Priess, E.Veldcamp, Demil Teketay and J.P.Lesschen. (2005). Assessment of Soil Nutient Depletion and Its Spatial Variability on Smallholders' Mixed Farming Systems in Ethiopia Using Partial Versus Full Nutrient Balances. Agriculture, Ecosystem and Environment, (108):1-16.

3. Asrat W. and Firew T. (2001). Utilization of tef in the Ethiopian diet. In: HailuTefera, Getachew Belay and Mark Sorrels (eds.). Narrowing the Rift: Tef Research and development. Proceedings of the International Workshop on Tef Genetics and Improvement, 16-19 October 2000, DebreZeit, Ethiopia, 239244 .

4. AUA (Alemaya University of Agriculture). (1989). Annual Research Report. Debre Zeit Agricultural Research Centre, DebreZeit, Ethiopia.

5. Ball, B. C. (1996). Cereal Production with Broadcast Seed and Reduced Tillage Review of Recent Experimental and Farming Experience. J. Agri. Eng. Res., 35(2): 71-95.

6. Ballock, A.W., A.M. Soomro, M.A. Javed. (2002). Optimum Plant Density for High Yield in Rice (Oryza sativa L.). Asian Journal of Plant Science. 1(1): 25-27.

7. Barber, S.A. (1994). Soil Nutrient Bioavailability: A Mechanical Approach. New York: John Wiley and Sons.

8. Bekele, E. (1985). A Review of Research on Diseases Of Barley, TEF, and Wheat in Ethiopia, p. 79-108. In: T. Abate (Ed.). A Review of Crop Protection Research in Ethiopia. Proc. First Ethiopian Crop 
Prod.Symp. Dept. Crop Protection, Inst. Agr. Res., Addis Ababa, Ethiopia.

9. Brady, N.C. and R.R. Weil. (2000). The Nature and Properties of Soils.13th ed. USA: Person Education Ltd.

10. Central Statistic Authority. (2010). Agricultural Sample Survey 2010/2011. Report on area and production for major crops (private peasant holdings Meher season), Addis Abeba, Ethiopia.

11. Chatterje, B.N. and S. Maite. (1985). Principles and Practices of Rice Growing, 2nd ed., New Delhi: Oxford and IBH publishing Co.

12. Cocucci. G.J. and H.V. Dallarosa. (1980). The Biology of Crop Productivity. San Francisco: Academic press London.

13. Debebe, A. (2005). Performance of F4 Progenies and Association among Yield and Yield Related Traits in TEF (Eragrostistef (Zucc) Trotter). Thesis. Ethiopia: Alemaya University.

14. Doris Piccinin, M.S.D. (2010). More about Ethiopian Food: Tef; Department of Nutrition and Food Science, University of Washington, America.

15. Epsien, E. (1992). Mineral nutrition of crops' principles and perspectives. John and Sons, New York.

16. Evans, L.T. (1993). Crop evolution, adaptation and yield 1 st ed. Cambridge University Press, New York, Port Chester. USA.

17. FAO. (2000). Fertilizers and Their use, 4th ed. International Fertilizer Industry Association. Food and Agriculture Organization of the United Nations. Rome, Italy.

18. Fufa H., Tesfa B., Hailu T., Kibebew A., Aberra D., and Seyfu K. (2001). Agronomy research in tef. In: Hailu Tefera, Getachew Belay and Mark Sorrels (eds.). Narrowing the Rift: Tef Research and development. Proceedings of the International Workshop on Tef Genetics and Improvement, 16-19 October 2000, DebreZeit, Ethiopia,pp.239-244 .

19. Guitard, A.A., J.A. Newman and P.B. Hoyt. (1961). The influence of seeding rate on yield and yield components of wheat, oats and barley. Canadian Journal of plant Sciences 1751-758.

20. Hailu Tefera and Seyfu Ketema. (2001).. Production and importance of tef in Ethiopian
Agriculture pp.3-7 In: HailuTefera, Getachew Belay and Mark Sorrels (eds.). Narrowing the Rift: Tef Research and development. Proceedings of International Workshop on Tef Genetics and Improvement, 16-17 October 2000. Addis Ababa, Ethiopia.

21. Hanekluas, S. (2007). Handbook of plant nutrition. Tailor and Francis. Boca Ratton, FL 33487-2742, USA.

22. Hay, R.K.M and A.J. Walker. (1992). An Introduction to Physiology of Crop Yield. Longman Scientific and Technical. New York.

23. Hunt, D. (1999). Farm power and machinery management, 8th ed., Iowa State University Press, Ames.

24. Khurana, L. N., and C. Chatterjee. (2002). Low sulphur alters boron metabolism of mustard. Journal of Plant Nutrition, 25(3): 29-44.

25. Legesse Amsalu. (2004). Response of tef [Eragrostistef (Zucc.) Trotter] to applied nitrogen and phosphorus in Sirinka, North Eastern Ethiopia. M.Sc. Thesis, Alemaya University. 68p.

26. Mangel, K. and E.A.Kirkby. (1996). Principles of Plant Nutrition. Panama Publishing Corporation.

27. Miller, M. H. 1996. Effects of nitrogen on phosphorus absorption by plants.pp: 643-683. In: E.W.Carson(ed.). The plant root and its environment. Proc. Institute Southern Regional Educational Board. Virginia Polytechnique Institute and State.

28. Miller, R.W. and R.L. Donahue. (1995). Soils in Ours Environment (7th ed). Pretice, Hall Englewood cliffs, Newgersey.

29. Minale Liban, Alemayehu Asefa, Tilahun Tadesse and Abraham Marye. (2004). The response of tef nitrogen and phosphorus application at Bichena and Yilmana-Densa areas, North-western Ethiopia, Crop.

30. Mitiku Melaku. (2008). Effects of seeding and nitrogen rates on yield and yield components of tef [Eragrostistef (Zucc.) Trotter]. M.SC. Thesis, Haramaya University, Haramaya, Ethiopia.

31. Mortvedt, J.J., et al. (Eds.). (1991). Micronutrients in Agriculture. No.4. Soil Science of America, Madison, wisc.

32. Mulubrhan Haile. (2005). The effects of Nitrogen, Phosphorus and Potassium 
fertilization on the yield and yield components of Potato (SolanumtuberosumL.) grown on Vertisols of Mekelle area. M.Sc. Thesis, Haramaya University, Haramaya, Ethiopia

33. National Academy Press. (1996). Lost crops of Africa volume 1, Grains. BOSTID National Research Council. National Academy Press. Washington, D.C.

34. New Dalhi, India. Martin, A. P. (1993). Tropical soils and fertilizer use. Intermediate Tropical Agriculture Series. University of Nairobi, Kenya.

35. Robson, A.D. and M.G., Pitman. (1993). Interaction between nutrients in higher plants. A.Lauchli and R.L. Bielski (Eds.). In: Encyclopedia of plant physiology Pp: 147-180, Springer-Verlag, Berlin, Germany.

36. Sanchez, P.A, Anne-Marie, I.I. Valencia and C.Pieri, 1996. Soil Fertility replenishment in Africa: A concept note. In: Proceeding of the workshop on developing African Agriculture: Achieving greater impact from research investments. September 26-30, 1995. Addis Ababa, Ethiopia.

37. Science Society of Ethiopia (CSSE). (2004). Sebil. vol.10 Proceedings of the tenth conference, 19-21, June 2004, Addis Ababa, Ethiopia.

38. Seyfu Ketema,1983. Studies of lodging floral biology and breeding techniques in tef [Eragrostis tef (Zucc.) Trotter]. Ph.D Thesis. London University, UK.

39. Seyfu Ketema. (1993). Tef (Eragrostistef). Breeding, agronomy, genetic resources, utilization, and role in Ethiopian agriculture. Institute of Agricultural Research, Addis Ababa, Ethiopia.

40. SeyfuKetema. 1997. Tef, [Eragrostistef(Zucc.) Trotter]. Promoting the conservation and use of Underutilized and neglected crops Biodiversity Institute, Addis Ababa, Ethiopia

41. Stallknecht, G.F., K.M. Gilbertson and J.L. Eckhoff. (1993). Tef: Food crop for humans and animals. Pp.231-234. In: J.J.Janick and J.E. Simon (eds.), New crops. Wiley, New York.

42. Tekalign Mamo, Selamyihun Kidanu, Mesfin Abebe and Teklu Erkosa. (1996). Review of soil fertility studies on Tef: Experience of Alemaya University of Agriculture. Alemaya University of Agriculture, Ethiopia.
43. Temesgen Kassahun. (2001). Effect of sowing date and nitrogen fertilization on yield and related traits of tef [Eragrostistef(Zucc.) Trotter] on Vertisols of Kobo area, Northern Wollo. M.Sc. Thesis Alemaya University, Alemaya, Ethiopia. 50p.

44. Tilahun Gelato. (1994). The effect of nitrogen fertilizer sources rates and time of application on the nitrogen uptake, grain yield and yield components of wheat. M.Sc. Thesis, Alemaya University of Agriculture, Alemaya, Ethiopia.

45. Tisdale, S.L., W.L. Nelson, J.D. Beaton and J.L Havalin. (1993). Soil Fertility and Fertilizer. 5th ed. Macmillan, publishing company, USA. PP. 109-174. 